\title{
Artigos
}

\section{Claudia Fonseca}

Universidade Federal do Rio Grande do Sul

\section{A certeza que pariu a dúvida: paternidade e DNA}

\begin{abstract}
Resumo: Atualmente, no Brasil, existe uma onda de testes de paternidade DNA (nos laboratórios públicos e em clínicas particulares) que levanta reflexões interessantes quanto à interseção das esferas médica e jurídica e sua influência sobre as relações de gênero e de parentesco na sociedade contemporânea. Para analisar esse fenômeno, acompanhamos nas diferentes instâncias jurídicas em Porto Alegre (na Defensoria da República, nas Audiências de Conciliação, na Vara de Família e no Serviço Médico do Tribunal) pessoas envolvidas em disputas jurídicas em torno da identidade paterna. Investigamos também como recentes mudanças nas leis de reconhecimento paterno são acionadas pelas diferentes personagens do cenário. A partir desses dados, levantamos a hipótese de que, longe de inspirar maior tranqüilidade, a simples existência do teste atiça as dúvidas. Tendo repercussões profundas sobre a nossa maneira de 'saber' quem é pai, a situação descrita nesse paper traz novos desafios para uma antropologia do conhecimento, voltada para a análise das crenças (inclusive científicas) ocidentais.
\end{abstract}

Palavras-chave: paternidade, reprodução, direito familiar, tecnologia do DNA, relações de gênero

Copyright (C) 2004 by Revista Estudos Feministas.

1 Esse paper foi apresentado na mesa-redonda Sexualidade, masculinidade e reprodução, durante o II Seminário Internacional e I Seminário NorteNordeste "Homens, sexualidade e repro-dução: tempos, práticas e vozes" (PAPAI/UFPE/UNICAMP), em Recife, de 17 a 20 de junho de 2003.
Atualmente, no Brasil, existe uma onda de testes de DNA (nos laboratórios públicos, com dinheiro do Estado, e em clínicas particulares) que desafia a imaginação. ${ }^{1}$ Interlocutores na televisão fazem prova de sua generosidade pagando o custo do teste para mães solteiras e maridos 'descornados'. Cidadãos em um vilarejo do Nordeste estão organizando consórcios - cada participante cotizando um tantinho por mês para ter acesso ao teste. Ouvi recentemente uma música no rádio em ritmo de samba com o seguinte refrão: "Não precisa fazer teste de DNA, a criança é a cara de você".

O que há (podemos perguntar) por trás de tanto alarido? Qual a idéia de paternidade sendo expressa aqui? E quais as eventuais conseqüências para a noção vigente de família? Para esboçar uma resposta inicial a essas perguntas, voltei minhas atenções para disputas em torno 


\footnotetext{
${ }^{2}$ No decorrer do ano de 2002, o custo do teste (envolvendo três pessoas - suposta mãe, suposto pai e filho) baixou nos laboratórios particulares de RS 2.000 para menos de R\$ 800 .

${ }^{3}$ Esse número, por sinal, não inclui os exames feitos nas clínicas particulares, sem nenhum mandado judicial - o que possivelmente faria dobrar a soma total.
}

\footnotetext{
${ }^{4}$ Esse quadro só muda a cada duas semanas, no "dia dos falecidos", quando aparecem mais adultos (ostentando muitas vezes uma situação socioeconômica melhor do que os clientes usuais), vindos para resolver a herança de algum parente defunto.
}

da identidade paterna - ações movidas na Justiça para reivindicar ou rescindir o reconhecimento paterno. Já que a grande maioria de casos é decidida pela tecnologia do DNA, esse material levanta reflexões interessantes quanto à interseção das esferas médica e jurídica e sua influência sobre as relações de gênero e de parentesco na sociedade contemporânea. Tendo repercussões profundas sobre a nossa maneira de 'saber' quem é pai, a situação descrita nesse paper também traz novos desafios para uma antropologia do conhecimento, voltada para a análise das crenças (inclusive científicas) ocidentais.

Desde 1999, e começando em São Paulo, o poder público está aceitando arcar com a demanda 'popular', pagando os testes com dinheiro dos cofres públicos. 0 estado do Rio Grande do Sul, onde realizei minha pesquisa de campo, mantém um convênio com a Universidade Federal para realizar exames levemente abaixo do preço 'normal'.' ${ }^{2}$ Na segunda metade de 2002, ingressavam no sistema gaúcho de justiça uma média de mil pedidos de investigação paterna por mês - um número que representa cerca de $7 \%$ do volume mensal de nascimentos. ${ }^{3}$ Marcando aproximadamente 500 testes por mês, o Serviço Médico Jurídico ainda tem uma lista de espera de mais de 8 mil pedidos - o que representa cerca de um ano e dez meses de fila. O mesmo fenômeno se repete em quase todos os estados da União.

A observação de uma manhã rotineira no Serviço Médico Jurídico revela uma circulação intensa de clientes. Vão chegando homens e mulheres dos quatro cantos do estado: a moça guarani da fronteira, a colona gringa da serra, a moradora de rua do litoral... Para muitas pessoas trata-se da primeira visita à capital. Chegam de madrugada, depois de sete ou oito horas de viagem, e vão embora com o ônibus do meio-dia. Algumas mulheres conseguem uma ajuda da prefeitura para pagar a passagem. Vêm escoltadas por uma assistente social, um advogado interiorano, algum parente ou até um companheiro... todas trazendo filhos a reboque. Com recém-nascidos no colo de suas mães e bebês engatinhando, a sala de espera tem ambiente de creche. ${ }^{4}$ Entre os filhos de pai desconhecido, ainda aparecem adolescentes, alguns dos quais tomaram a iniciativa eles mesmos de localizar o genitor. Os supostos pais, vindos em geral sozinhos, parecem pouco à vontade. São eles que ocupam as cadeiras mais afastadas da secretaria, ou que ficam em pé, às margens da cena. Alguns deles, ostentando seu status de brigadiano ou militar (fardados viajam de graça no ônibus intermunicipal), demoram para responder à chamada. "É como se tivessem vergonha", 
${ }^{5}$ É uma coincidência irônica que a tecnologia envolvida nos testes de DNA de paternidade se torne acessível quase ao mesmo tempo em que a lei passa a cobrar, como nunca antes, obrigações do pai em relação aos seus filhos (Elisabete BILAC, 1999).

- Conforme uma mãe, seu filho adolescente desistiu porque "viu tudo aquilo no Ratinho e achou tudo aquilo muito feio!". comenta para mim a recepcionista. "Às vezes tenho que chamar duas ou três vezes antes que se manifestem." Em todo caso, a cena nessa sala de espera não deixa dúvidas quanto ao alcance do teste. O impacto dessa nova tecnologia chega aos lugarejos mais interioranos e a todas as classes sociais.

O fato de a maioria dos testes de paternidade serem iniciativa das mulheres leva a crer que são elas que mais se beneficiam da nova tecnologia. Essa hipótese coincide com as evidentes boas intenções dos legisladores e juristas que apresentam as novas leis de paternidade como um meio para fortalecer a causa da mulher e da criança contra as clássicas prerrogativas patriarcais. ${ }^{5}$ Pretendem, com tais medidas, 'dar um pai' a crianças 'de pai desconhecido', mas - podemos perguntar - 'pai' em que sentido? Será que essa aliança entre lei e ciência está surtindo, na prática, os efeitos almejados?

Muitos casos nem chegam a ser julgados. Alguns processos são arquivados porque ninguém conseguiu localizar o suposto pai. Mesmo quando localizado, é comum o homem não comparecer à primeira convocação para fazer o exame. Uma mãe pode cansar de 'caminhar', ou seu filho, quando maior, pode resistir em enfrentar 0 encontro tenso com um suposto pai desconhecido. ${ }^{6}$ Há, de fato, muitos motivos para uma pessoa desistir. De toda maneira, em um levantamento sobre 20 dias do Serviço Médico, constatamos que cerca da metade dos exames não foi realizada porque um dos envolvidos não compareceu.

Certamente, na grande maioria de casos que são finalmente julgados na Vara de Família, o jovem consegue colocar na certidão o nome de algum 'pai'. E, se é menor de idade, o juiz mandará o pai pagar uma pensão modesta (em torno de $30 \%$ do salário mínimo). Porém, ao que tudo indica, na ausência de uma mínima relação anterior entre pai e filho, essa 'identidade' oficial nem sempre traz conseqüências no plano prático - no que diz respeito ao sustento material -, e muito menos no plano afetivo. Nada garante que o homem declarado pela corte como o pai de certa criança cumpra seu compromisso paterno. Há de se convir: a afirmação de um fato biogenético, o cumprimento de uma lei e o desenvolvimento de uma relação social são processos distintos. Hoje, a ciência fornece meios para identificar esse pai e, assim, atribuir estas obrigações a um indivíduo preciso.

"Mal não faz", insiste um dos meus interlocutores, referindo-se ao teste de DNA. Mas, considerando o peso no orçamento público - o que, dependendo do estado, chega a meio milhão de reais por mês -, cabe indagar se esse é 
7 Ver Marilyn STRATHERN, 1992, 1995a e 1995b.

${ }^{8}$ Claudia FONSECA, 2002. realmente um gasto prioritário. Em suma, neste artigo, pergunto se o teste de DNA não tem sido abraçado de forma precipitada pelos poderes públicos (sem falar da 'opinião pública'). Será que os legisladores não estão procurando, nessa forma supostamente neutra de biotecnologia, uma solução simples para um problema complexo? Será que têm medido as conseqüências da 'sacralização' desse teste enquanto prova última de um parentesco que durante toda a história tem sido construído de forma social? Será que têm refletido sobre as conseqüências dessa forma de biologização das relações familiares?

As implicações das novas tecnologias - o que estão mudando na nossa maneira de imaginar o 'natural' - são vastas e profundas, tendo dado origem a inquéritos públicos em diversos países. ${ }^{7}$ Por enquanto, no âmbito dos estudos da masculinidade, proponho refletir sobre um ponto apenas dessa problemática - a possível maneira em que o teste tem exacerbado dúvidas masculinas quanto à paternidade. Pois, se, por um lado, o teste pode ser usado para firmar um laço de parentesco, por outro lado, pode ser usado para negar laços já existentes. Isto é, pode servir tanto na investigação quanto na contestação da paternidade.

Em um primeiro trabalho sobre esse tema, ${ }^{8}$ evoquei a famosa heroína de Machado de Assis, Capitu, para sugerir que a tecnologia do DNA representava uma arma potencial a ser usada por maridos ciumentos para desmascarar as supostas aventuras de suas esposas. ${ }^{9}$ Desde então, ${ }^{10}$ tendo acompanhado - além de processos no papel - pessoas (na Defensoria da República, nas audiências de conciliação e no serviço médico), sugiro que essa possibilidade, embora permaneça relevante, precisa ser repensada. Hoje, é minha impressão - uma impressão que tentarei elaborar neste curto espaço - que o potencial do teste para anular laços de filiação, longe de representar uma vitória dos homens, reforça angústias latentes.

\section{A perspectiva: estudos da masculinidade}

Minhas reflexões se inserem no campo de discussão, rica e complexa, sobre masculinidade. Ondina Leal e Adriana Boff ${ }^{11}$ estão entre os primeiros a chamar a atenção para a tendência, nas pesquisas sobre a masculinidade, de ressaltar a sexualidade não-reprodutiva. Diante da omissão de qualquer menção da reprodução, esta permanecia um assunto quase exclusivamente feminino. (A sexualidade era para os homens como a reprodução era para as mulheres - 'natural'.)'12 Nesse sentido, houve um avanço nos últimos tempos, com o surgimento de pesquisas sobre a saúde reprodutiva masculina e a 
13 Jorge Lyra DA FONSECA, 1998; Karen GIFFIN e Cristine CAVALCANTI, 1999; e BILAC, 1999. Ver também o dossiê organizado por Luzinete Simões Minella e Maria Juracy Toneli Siqueira sobre "Relações de gênero e saúde reprodutiva", na Revista de Estudos Feministas, v. 8, n. 1, 2000. ${ }^{14}$ Maria Juracy SIQUEIRA, 1997; GUTMANN, 1996; e LONGHI, 2001.

${ }^{15}$ Socrates NOLASCO, 1995.

${ }^{16}$ Miguel Vale de ALMEIDA, 1995; e Robert W. CONNELL, 1987.
17 Russel Parry SCOTT, 1990; Margareth ARILHA, 1998; Ceres VICTORA, 1992; Heloisa PAIM, 1998; e Paula CAMBOIM, 2002.

18 Notáveis exceções incluem GUTMANN, 1996, sobre mexicanos de grupos populares que cuidam dos seus enteados; Gláucia MARCONDES, 2003, e Sandra RIDENTI, 1998, sobre brasileiros das camadas médias; e Didier LEGALL e Claude MARTIN, 1995, sobre diferentes camadas no quadro francês. Todos trazem perspec-tivas originais em um campo que parece pressupor a normalidade estatística da família biológica conjugal. paternidade. ${ }^{13}$ Estereótipos - por exemplo, o do macho latino, associado ao pai frio e autoritário - foram desconstruídos. Surgiram estudos etnográficos revelando homens que se dedicam aos cuidados carinhosos dos filhos pequenos, que zelam pela educação moral e profissional dos filhos adolescentes e que procuram a companhia dos seus filhos adultos para compartilhar momentos lúdicos. ${ }^{14}$ Ainda que apontem para certas tendências gerais (do "novo homem"), ${ }^{15}$ esses estudos enfatizam a diversidade de modelos e comportamentos paternos na sociedade contemporânea. ${ }^{16}$

Um elemento que a maioria de estudos tem em comum, e que serve como ponto de partida de minha análise, é a noção de que, seja qual for o modelo que emula, o homem sente uma forte dose de ambivalência quanto ao seu lugar na família que pretende constituir. Muitos, sem emprego fixo e sem dinheiro para cumprir seu papel de provedor, não conseguem realizar a contento o modelo de pai/marido 'antigo'. Outros, mesmo tendo renda suficiente para cumprir com o dever financeiro, não sabem lidar com os modelos 'novos' de comportamento - do casal igualitário e da mulher independente. A ambivalência que o homem sente em relação à paternidade faria parte de um quadro geral da chamada 'crise de masculinidade'.

A literatura sobre a América Latina sugere uma diferença importante entre atitudes masculinas e femininas em relação ao nascimento de um filho. Enquanto as mulheres querem nenês, os homens querem família, isto é, enquanto o ideal para os dois é, evidentemente, casal+filhos, a mulher ainda consegue imaginar uma realização pessoal no papel materno até sem marido. 0 homem, por outro lado, embora possa se gabar de uma gravidez como prova de sua virilidade, raramente encara com prazer uma relação com o filho sem que a mãe deste seja identificada como sua companheira. Em outras palavras, o ideal masculino é primeiro constituir a família (casal+casa), depois assumir filhos. Imagina-se um momento quando o homem toma uma decisão deliberada de abrir mão das prerrogativas de solteiro (pouca responsabilidade, muita 'farra') para assumir uma nova etapa de vida como chefe de família. Nesse sentido, a gravidez não planejada é vista pelos homens, se não como uma estratégia feminina para 'amarrar' um namorado recalcitrante, pelo menos como uma queima de etapas. ${ }^{17}$

Nos meus dados, a ambivalência paterna salta aos olhos por causa do recorte metodológico. Em vez de enfocar, como a maioria de pesquisas, o pai que convive com seus filhos na família conjugal, ${ }^{18}$ considero os homens que recusam se declarar 'espontaneamente' como pai ou, 
${ }^{19}$ COSTA, 2002.

20 Cada lugar merece uma discussão metodológica diferente que não cabe no espaço deste artigo. Cabe frisar que recebi uma acolhida amistosa em todas as instâncias do Judiciário por onde transitei. ainda, que procuram anular seu status já declarado de pai. O material tem a vantagem de mostrar a sexualidade e a reprodução como duas faces de uma mesma moeda. Nas disputas sobre a identidade paterna legal, as práticas heterossexuais masculinas revelam-se como indissociáveis da vontade (ou não) de ser pai.

Rosely Costa, ${ }^{19}$ na sua análise dos estudos da masculinidade, frisa a necessidade de os pesquisadores desse campo aprenderem com os erros dos antigos estudos da mulher. Visto à luz das teorias recentes de gênero, o 'homem' não apareceria como uma categoria unitária. $O$ objeto de análise seria 'homens', no plural, sujeitos a influências diversas conforme fatores contextuais de classe, geração, cor, orientação sexual, etc. Nessa perspectiva, não existe 'o homem' genérico, adversário 'da mulher'. Existem personagens concretas, negociando suas relações em bases políticas e sociais específicas. Respondendo a críticas feministas, Costa sugere que essa abordagem, longe de despolitizar o estudo acadêmico, serve para examinar complexas jogadas envolvendo táticas individuais e forças institucionais em uma disputa constante pela hegemonia - isto é, pelo direito de definir o certo e o verdadeiro. É nesse espírito que proponho ler as diversas histórias que coletei durante minha pesquisa. Não vejo os conflitos examinados aqui como resultado 'natural' de uma guerra dos sexos, mas antes como parte de um campo conturbado, envolvendo o judiciário e a 'ciência' médica, em que se constituem e se reconstituem, em um jogo dinâmico, representações de família, companheiro e pai.

\section{O material: a paternidade contestada}

Nessa fase de minha pesquisa sobre os processos de investigação de paternidade (realizada - quase sempre - com a tecnologia do DNA), concentrei meus esforços na capital do estado, Porto Alegre. Segui os usuários do sistema público, desde o primeiro contato na Defensoria, e as tentativas de conciliação no Fórum Central, até a sala de coleta de sangue no Tribunal de Justiça e as sentenças finais na Vara de Família. ${ }^{20}$

Os dados etnográficos e documentais que juntei sobre as investigações de paternidade se prestam a muitos tipos de análise. Obrigada a fazer um recorte que coubesse nesta breve exposição, resolvi me concentrar nos negatórios de paternidade - isto é, casos em que o homem procura desfazer um vínculo legal que já existe. Deixo fora, por enquanto, as interessantíssimas disputas entre homens casados e suas amantes - disputas que revelam muito sobre processos de desigualdade de classe e sexo no Brasil. 
Também deixo de lado, por enquanto, os casos envolvendo jovens solteiros, muitos dos quais assumem a paternidade de uma criança sem grande protesto. Aqui, quero apenas frisar que todos os casos apontam para o caráter eminentemente social (e não biológico) do sentimento paterno, pois passa, antes de tudo, pela relação que o homem tem com a mãe da criança. O sangue conta, sim - tanto que a paternidade 'social', na maioria dos casos, se calca na crença de uma relação biológica. No entanto, há homens que, por não terem afinidades com a mulher, rejeitam qualquer relação com o filho; e, contrariamente, existem homens (em particular padrastos) que assumem 0 status paterno, mesmo sabendo que não existe fundamento biológico nenhum para essa relação. Ao que tudo indica, a biologia nunca foi o sine qua non da paternidade certamente não da perspectiva dos homens.

Para lançar a discussão sobre a chamada 'contestação de paternidade', parto de um anúncio pregado na parede da Defensoria central de Porto Alegre. Fica atrás da mesa dos defensores, presumivelmente para esclarecer as dúvidas dos profissionais que ali atuam.

Ação de Anulação de Reconhecimento de Filho - Hipótese de alegado erro.

Não se trata aqui de revogação do reconhecimento, mas sim, da hipótese de erro. Não há que invocar aqui a irrevogabilidade do reconhecimento. Irrevogabilidade ocorre na hipótese daquele pai que mesmo sabendo que não é pai, e tendo perfeita consciência disto, faz o registro da criança como seu filho e depois pretende desfazer o reconhecimento, e é a esse pai que temos negado a ação.

Esse trecho da sentença de um juiz fala de diferentes tipos de paternidade - alguns legalmente revogáveis, outros não. Nosso desafio é decifrar e contextualizar o pequeno parágrafo, para que ele nos fale não somente da resposta jurídica, mas também da demanda que os usuários estão apresentando aos serviços do Estado.

\section{Pais/padrastos na adoção à brasileira...}

Falemos primeiro "daquele pai que mesmo sabendo que não é pai, e tendo perfeita consciência disto, faz o registro da criança como seu filho". Quem faz isso? Nove vezes em dez é o novo companheiro de uma mãe solteira. 
${ }^{21}$ Observações feitas com base em minhas pesquisas etnográficas de grupos populares (FONSECA, 1995 e 2000).
22 Neste artigo, todos os nomes foram trocados para garantir 0 anonimato dos indivíduos envolvidos.

${ }^{23}$ GUTMANN, 1996; MARCONDES, 2003; e LEGALL e MARTIN, 1995.

${ }_{24}$ Observa-se que a soma de divórcios e desquites no Rio Grande do Sul beirou, no ano 2000, 16 mil casos, enquanto que ocorreram cerca de $45 \mathrm{mil}$ casamentos. Podemos inferir, com base nesses dados, que a taxa de separação no Rio Grande do Sul aproxima-se à da França - cerca de $30 \%$. No entanto, devemos lembrar que esses números não incluem o quarto da população vivendo maritalmente que nunca formalizou sua união (ver também Maria Coleta OLIVEIRA, 1996).
Em outras palavras, o homem que seria normalmente conhecido como 'padrasto' escolhe conscientemente a identidade de 'pai'. Alguns fazem isso na época de seu casamento, mas muitos não chegam a casar. Nesse caso, parece que registrar o filho da companheira quase que substitui o casamento, servindo para marcar a nova aliança entre homem e mulher. ${ }^{21} \mathrm{Em}$ todo caso, trata-se daquilo que os juízes rotulam como 'adoção à brasileira' - um ato inteiramente ilegal, uma forma de 'falsidade ideológica', passível de multa e pena de prisão. Apesar de ser um procedimento bastante comum, não encontrei um só caso de punição. Pelo contrário, nos processos consultados, os advogados costumam se referir à 'evidente nobreza de espírito' que move um homem a assumir, dessa forma, a identidade paterna.

Encontrei exemplos de adoção à brasileira em todos os espaços por onde transitei. Na sala de espera da Defensoria, uma moça que veio processar o (suposto) pai de seu nenê tece elogios ao sentido de responsabilidade de seu próprio pai:

Minha mãe ganhou meu irmão antes de mim, mas o pai dele não registrou. Só foi registrado dez anos mais tarde, quando minha mãe se juntou com meu pai. Aí meu pai registrou. Meu irmão já tinha idade de dizer se queria ou não. Queria, e meu pai também. A minha mãe chegou a dizer para ele: "Ah, fulano aí é teu pai..." Mas meu irmão dizia que não era coisa nenhuma, que pai era quem criou ele. E quando o pai baixou hospital, Deus me livre, meu irmão veio correndo para cuidar dele. Agora, quando foi a vez da mãe... ele quase não deu bola. (Ana Lúcia, ${ }^{22} 24$ anos, afro-brasileira, trabalha como babá sem carteira assinada.)

Sugiro que a adoção à brasileira praticada por padrastos procurando estabelecer um vínculo oficial com seus enteados é apenas o topo do iceberg de um fenômeno muito mais amplo. Quantos homens não cumprem esse papel de pai/padrasto? E, no entanto, com raras exceções, ${ }^{23}$ o fenômeno de padrastos tem sido pouco estudado, seja com métodos qualitativos, seja com métodos quantitativos. ${ }^{24}$ É interessante notar que, em diversos países ocidentais, boa parte das adoções legais são efetivadas por cônjuges querendo legalizar sua relação paterna ou materna com o rebento de seu cônjuge. Apesar de ser permitido pela legislação brasileira, tal procedimento é, na prática, raro no Brasil. Minha impressão é que os padrastos brasileiros não assumem menos essa paternidade, mas que eles tendem a formalizar seu laço com o enteado de maneira ilegal - pela 'falsidade ideológica', ou seja, pela adoção à brasileira. 


\section{Evolução da legislação sobre contestação de paternidade}

Há motivo para pensar que não são poucas as adoções à brasileira efetuadas por padrastos no Brasil. Uma maneira para detectar esses casos surge justamente quando os pais declarados procuram, depois de uma separação conjugal, voltar atrás, negando sua paternidade por via de um teste de DNA. Nessas circunstâncias, o que faz o tribunal? Tal paternidade é revogável ou não? $O$ primeiro artigo da Lei 8.560/92, regulando a paternidade dos filhos havidos fora do casamento, reza que "O reconhecimento dos filhos havidos fora do casamento é irrevogável..." Ponto final. Não há prevista nenhuma ressalva que abra para esse tipo de pai declarado a possibilidade de voltar atrás. Tem status semelhante ao de pai adotivo: escolheu essa condição, vai ter que arcar com as conseqüências. O Novo Código Civil (Lei 10.406, de 10 de janeiro de 2002) guardou ipsis litteris essa cláusula.

No entanto, existe uma diversidade de referências legais a partir das quais um juiz pode formular sua decisão. Assim, ao olharmos para a evolução da legislação no tocante a filhos havidos 'na constância do casamento', constatamos uma tendência de facilitar cada vez mais a contestação da paternidade. De acordo com o Código Civil Brasileiro de 1916, um homem casado era legalmente pai dos filhos de sua mulher se estes fossem nascidos nos 180 dias subseqüentes ao casamento ou nos 300 dias subseqüentes à dissolução conjugal. Qualquer criança nascida antes dos 180 dias depois do casamento era presumidamente do marido se ele soubesse que a mulher estava grávida por ocasião do casamento ou se ele voluntariamente registrasse o filho em seu nome. Se o casal vivesse sob o mesmo teto, o adultério da mulher (nem mesmo com sua 'confissão') não seria o bastante para contestar a paternidade de seu filho. Os únicos fundamentos para a negação da paternidade (e, mesmo então, havia um limite de dois meses após o nascimento da criança para efetuá-la) eram a impotência completa ou a separação prolongada em residências separadas (veja o Código Civil, artigos 338 a 346).

Em 1943, a Lei 5.860 ampliou as possibilidades de contestação com o seguinte acréscimo (em itálicos) ao artigo 348: "Ninguém pode vindicar estado contrário ao que resulta do registro de nascimento, salvo provando-se erro ou falsidade do registro". De forma significativa, o Novo Código Civil (2003) mantém essa ressalva ao mesmo tempo que elimina as restrições tradicionais. Agora, um homem pode contestar a paternidade de um filho sem ter que 
25 Ministro Eduardo Ribeiro, 194866/RS, 1998/0084082-6, 20/ 04/1999. comprovar a impotência absoluta e sem preocupação de prazo:

Art. 1.601: Cabe ao marido o direito de contestar a paternidade dos filhos nascidos de sua mulher, sendo tal ação imprescritível.

Não pode haver dúvida quanto à relação entre o teste DNA de paternidade (popularizado no mundo inteiro na década de 1990) e essa última mudança da legislação outorgando ao homem o direito praticamente irrestrito de contestar a paternidade dos filhos havidos durante 0 casamento. Vide a seguinte sentença, dada por um juiz do Superior Tribunal Federal em 1999:

As normas jurídicas hão de ser entendidas, tendo em vista o contexto legal em que [são] inseridas e considerando os valores tidos como válidos em determinado momento histórico. Não há como interpretar-se uma disposição, ignorando as profundas modificações por que passou a sociedade, desprezando os avanços da ciência e deixando de ter em conta as alterações de outras normas, pertinentes aos mesmos institutos jurídicos. Nos tempos atuais não se justifica que a contestação da paternidade, pelo marido, dos filhos nascidos de sua mulher, se restrinja às hipóteses do artigo 340 do Código Civil, quando a ciência fornece métodos notavelmente seguros para verificar a existência de vínculo de filiação... ${ }^{25}$

É, portanto, interessante notar que, se em certas circunstâncias houve um movimento na direção da irrevogabilidade do reconhecimento paterno para filhos havidos fora do casamento, houve uma evolução no sentido inverso no que diz respeito à contestação de paternidade de filhos (que até 1992 teriam sido denominados) 'legítimos'. A adoção à brasileira, apesar de envolver falsidade, cai tecnicamente na primeira categoria, pois se trata da declaração de filhos extraconjugais. Assim, como vimos no aviso na parede, nessa defensoria, existe uma orientação para desencorajar os pais declarados arrependidos, invocando a lei de 1992. A única exceção a tal política diz respeito aos casos em que o pai declarado vem acompanhado do suposto pai biológico, procurando efetivar uma troca de nomes na certidão da criança. Nesse caso, invoca-se o 'interesse da criança', que 'tem o direito de saber quem é o verdadeiro pai', e toma-se cuidado para acoplar ao negatório um processo de investigação de paternidade que nomeia o novo pai. Em uma dezena de sessões que observei na corte de conciliação, levantei já três casos em que os adultos em questão procuravam anular uma adoção à brasileira. Curiosamente, em dois desses casos, o pai 
declarado continuava morando com a mãe da criança, cumprindo o papel paterno, mas, para ajudar seu filho a acessar uma herança ou regularizar uma pensão alimentícia, estava pronto para ver seu nome substituído na certidão de nascimento pelo do pai 'verdadeiro'.

A 'absoluta prioridade' que deve ser legalmente atribuída aos direitos da criança (Estatuto da Criança e do Adolescente, artigo $4^{\circ}$ ) abre a porta para novas leituras sobre a filiação legal. Aproveitando-se da imensa variedade de interpretações possíveis quanto ao 'melhor interesse' da criança, um advogado pode pretender que a irrevogabilidade do status paterno é prejudicial ao filho. Assim, tecnicamente, o direito da criança de saber 'a verdade' sobre suas origens pode ser invocado para acobertar o desejo de um homem desfazer o vínculo pai-filho.

Nos parágrafos que seguem, proponho considerar, através do estudo de alguns casos concretos, a maneira como essas diversas possibilidades legais funcionam na prática. Qual a demanda dos usuários? Qual a reação dos operadores da Justiça?

\section{A quem o direito?}

João Vitor, 29 anos, formou-se torneiro mecânico, mas ganha a vida transportando objetos e pessoas na sua minivan. Conheci-o na Defensoria Estadual, onde ele esperava na fila para pedir um teste de DNA. Depois de oito anos de casamento, separou-se da mulher, e queria 'tirar uma dúvida' sobre a paternidade de sua filha, já com quase 6 anos. Mora com seus pais, donos de uma lavanderia no centro de Porto Alegre. "Nós que criamos minha filha", ele me explica-mas, logo, acrescenta que a criança passa a metade da semana com a mãe dela. Garante-me que, seja qual for o resultado do teste, "não vai fazer diferença, vamos continuar igual como estamos". Porém, insiste muito no seu direito de saber: "Só quero tirar uma dúvida. Não quero viver com essa dúvida pelo resto da minha vida. Não sei por que [aqui na Defensoria] eles pedem tanta coisa. É meu direito saber". Eu sugiro que é por causa do preço do teste, e ele responde: "Ah, para pagar político, eles têm dinheiro, tiram dinheiro de nós, vai imposto por qualquer coisa, mas para garantir os direitos da gente, está em falta!"

Com toda certeza, eu não teria conhecido João Vitor se tivesse ficado apenas no Serviço Médico ou mesmo na Vara de Família - isto é, nas etapas 'posteriores' da investigação de paternidade. Os casos como o dele não vão em geral além da Defensoria - os defensores explicam para homens descasados que 'seria difícil' o juiz acatar esse tipo de negatório sem que houvesse outro 'pai' pronto 
${ }^{26}$ Durante nossa conversa, João Vitor esbraveja contra a instituição do casamento, dizendo que "isso não existe mais; agora, os casais têm que renovar o contrato de seis em seis meses diante do juiz".

27 Processo de investigação de paternidade iniciado em 1999. para assumir seu lugar na certidão. De fato, tudo que João Vitor conseguiu no local foi um ofício de encaminhamento para a Santa Casa, onde ele teria de pagar em torno de RS 500 (um preço de convênio) para realizar um exame com tecnologia considerada menos precisa (HLA). Mas não deixa de ser significativo que no primeiro mês de nosso trabalho na Defensoria, tomando nota de todos os novos casos de investigação que passavam pela instituição, aproximadamente um terço dos casos eram iniciados por homens. Observei jovens que, já tendo declarado o filho, suposto fruto de uma relação passageira, começaram a estranhar qualquer coisa: "ela não me deixa chegar perto", "na hora de exercer alguma autoridade, ela não deixa de jeito nenhum". As defensoras com as quais falei também têm muitas histórias para contar: um homem, por exemplo, que, depois de se separar, criou seus dois filhos sozinho... e, ainda, depois de vê-los crescidos, foi pedir exame de DNA 'para tirar uma dúvida'. Tendo rompido (ou nunca iniciado) a relação de casal, esses homens procuravam no teste de DNA uma justificativa para repensar um outro vínculo (de filiação), visto, evidentemente, como subsidiário da relação conjugal.

$\mathrm{Na}$ verdade, muitas das petições iniciadas por mulheres revelam histórias semelhantes à de João Vitor falam de homens que, apesar de terem vivido durante longos anos com uma companheira, questionam a paternidade dos filhos que criaram. A diferença é que João Vitor era legalmente casado com sua mulher e, assim, era automaticamente $\mathrm{o}$ pai presumido de sua filha. ${ }^{26}$ No caso de $25 \%$ da população que vive em união consensual, a filiação paterna não é automática; deve ser voluntariamente declarada pelo pai - o que significa, na prática, que depende dos poderes de persuasão da mulher. A ex-mulher do jardineiro Eloi, por exemplo, exigiu que ele declarasse seus três filhos, nascidos durante quase 15 anos de convivência. Ele contestou, dizendo no processo ${ }^{27}$ que "... não nega que viveu com [ela], e portanto não concorda com a alegação de que não quis reconhecer seus filhos. Ocorre que [ele] não reconheceu os filhos [...] como filhos, pois nunca teve certeza da paternidade" (ênfase minha). Considerando o homem de renda modesta, o juiz concedeu assistência gratuita, com benefício do teste de DNA, que, por três vezes, deu resultado positivo. É interessante que, apesar de ouvir testemunhas e receber ampla prova da convivência conjugal desse homem com a mãe das crianças, o juiz ainda exigiu uma 'prova contundente' (isto é, o exame de DNA), antes de declará-lo pai delas.

Mesmo em situações em que o homem está realmente a ponto de assumir - por exemplo, o caso de um senhor que, ao constatar a incrível semelhança física 
entre ele e seu filho, já tinha feito um acordo amigável com sua ex-namorada - as pessoas ainda chegam diante do poder público com a mesma demanda: "Se tiver direito [ao teste], eu quero". Em resposta à demanda desses indivíduos - mulheres reclamando o reconhecimento paterno para seus filhos 'de pai desconhecido' e homens solteiros querendo 'tirar uma dúvida' - os operadores das varas de família tendem a conceder assistência jurídica gratuita com bastante facilidade. Agindo sem dúvida com espírito democrático, querendo garantir direitos iguais a todos que chegaram até esse ponto, é raro que neguem o pedido por um exame pago pelo Estado. Ao que tudo indica, quando se trata de estabelecer um vínculo paterno legal para uma criança que até então não tinha nenhum, já virou quase rotina mandar fazer o teste de DNA. Existe uma aceitação tácita da 'normalidade' de o homem exigir esse 'direito', deixando a ciência decidir os fatos, antes de ele assumir um compromisso tão sério.

Contudo, o poder público não trata todas as demandas da mesma forma. Como vimos no caso de João Vitor, mesmo se tecnicamente a lei favorece a contestação do homem casado, de fato o sistema judiciário aciona mecanismos para desencorajar esses Dom Casmurros da época contemporânea, obrigando a grande maioria deles a pagar o preço do teste de DNA em um dos cinco laboratórios particulares locais. É só depois de eles voltarem com resultado negativo que os defensores acatam sua demanda, ajuizando o processo e mandando-o para o Fórum. É nesse momento que é invocada, ao lado do 'direito de a criança saber', 'a hipótese de erro', citada acima. Contrariamente à questão de 'falsidade', 'a hipótese de erro' diz respeito a casos em que o homem 'errou' em boa consciência - subentendendose que foi enganado pela mulher.

Para entender as conseqüências sociais e emocionais de tal processo, proponho agora narrar um último caso que presenciei durante a pesquisa de campo.

\section{De quem o interesse?}

Verão de 2002. Estou no sétimo andar do Fórum Central, na sala reservada especialmente para possíveis 'conciliações' ligadas a processos tramitando na Vara de Família. A sala é pequena. Na frente de três mesinhas que formam uma letra ' $U$ ', mal há lugar para as quatro cadeiras enfileiradas contra a parede para eventuais espectadores que nem eu. À direita, esperam as cadeiras do 'réu' e de seu advogado (ou defensor); à esquerda, as do 'requerente' com seu advogado. O juiz e o promotor sentarão na nossa frente, um grau acima dos outros participantes da cena e 
um grau abaixo de (um retrato de) Jesus Cristo. Num canto, atrás de seu computador, o escrivão puxa documentos relevantes ao próximo litígio.

Nessa manhã, noto que o escrivão e a promotora (chegada agora para iniciar a sessão) estão particularmente tensos e acabam trocando comentários sobre o próximo caso. Já viram muitas outras 'investigações de paternidade' - de jovens recalcitrantes, de homens casados, de parceiros que abandonam o lar sem nunca ter casado nem registrado os filhos - mas esse caso é diferente. Trata-se de um homem que, depois de ter se comportado durante 12 anos como pai exemplar, está pedindo para anular a certidão de nascimento de seu filho, apagando seu nome do registro. Que tipo de homem faria isso?

Estou levemente surpresa ao ver entrar na sala de audiências um quarentão, grande mas de jeito tímido, usando óculos à la John Lennon. Exala um ar não de triunfo, mas de tragédia. Calado, toma seu lugar ao lado de sua advogada, em frente à mãe de seu filho e o advogado dela. Enquanto esperamos a volta do juiz (que, hoje, atende simultaneamente em duas salas contíguas, uma audiência em cada quinze minutos), folheio o processo, inteirandome dos fatos básicos do caso tal como esse pai renegado, junto com seu advogado, os apresentam.

Alceu, o homem em questão, é um carpinteiro aparentemente bem-sucedido que mora em um bairro de classe média. Frisa, no seu processo, que o nascimento desse filho foi motivo de grande alegria para ele e toda sua família. Apesar de nunca ter vivido com sua companheira (alegando 'o mau gênio' dela), mantinha estreitos contatos com o filho, levando-o freqüentemente a passear junto com os avós e outros parentes paternos. Os anos foram passando, o menino cresceu, e Alceu constituiu uma nova família. Até que um dia, revendo os álbuns de família e notando a falta de semelhança entre o menino e qualquer parente seu, "foi cogitada a idéia de que o menor talvez não fosse seu filho legítimo [...] Infelizmente, nesses casos e no nosso próprio dia-a-dia, sempre tem uma tia, uma vizinha ou uma prima que sabe de alguma coisa do passado". A dúvida passou a atormentar Alceu durante noites a fio até que, finalmente, com dinheiro poupado de seus parcos recursos, aproveitou um dos passeios semanais com seu filho, já com 11 anos, para fazer um teste de DNA. O resultado negativo constatado pelo laboratório particular deu origem a um primeiro processo.

Na escrita de sua petição sobressai a angústia de todo o círculo familiar de Alceu. Aprendemos que, quando os pais e familiares do suposto pai souberam do resultado, 
"foi terrível, não aceitaram o óbvio, e foram veementes ao afirmar que o teste de DNA só podia estar errado, que o laboratório não era confiável, enfim, usaram todo o tipo de argumento para tentar negar a realidade". Ainda mais, a mãe do menino insistia com toda convicção de que não havia namorado ninguém naquela época além de Alceu e que o resultado só podia estar errado. Tamanha foi a oposição que Alceu acabou desistindo desse primeiro processo. Passou quase um ano antes de ele voltar para o tribunal. Agora está determinado a levar adiante seu caso, inclusive com resultado (mais uma vez negativo) de um novo teste de DNA encomendado pelo tribunal.

Os argumentos do processo carregam nos valores convencionais, sem dúvida para ressaltar o ultraje perpetrado contra o autor. Contudo, a linguagem acaba por convencer o leitor de um sofrimento que vai além de frases de efeito:

Realmente a questão é dramática e extremamente difícil pois não se trata apenas de direitos e obrigações, mas principalmente de sentimentos. Ainda que haja afeto entre pai e filho, agora também está presente o sentimento de traição e vergonha, de humilhação... Ora, é certo que a criança não tem culpa de nada, mas e o autor [Alceu], será que alguém pensa como ele se sente no seu íntimo, sendo enganado durante todos esses anos, acreditando ter um filho que não é seu?

"Bem", a promotora rompe o silêncio, trazendo-me de volta para a cena do tribunal : "Será que tem possibilidade de um acordo?" Sua pergunta parece sem convicção. Diante do mutismo das partes, a promotora, sem ânimo, esboça alguns argumentos para suspender o processo: "Trata-se de um menino de 12 anos que está perdendo a família... Existe um claro conflito de interesses entre o menino e seu pai... O menino está sendo penalizado por um ato que não é da responsabilidade dele..." Frases respondidas com a simples afirmação da advogada de Alceu: "O menino tem direito de saber quem é o verdadeiro pai". Evidentemente, seu argumento não convence a todos. A advogada da mãe sublinha que, como seqüela do processo, o menino está em tratamento psicológico, ao que a promotora responde, em um suspiro apenas perceptível: "Só pode". O aparente desconforto de Alceu sugere que nem ele acredita na alegação de sua advogada.

A mãe do menino não abre a boca; seu excompanheiro, idem. O clima de velório não muda com a chegada do juiz. Pairando sobre todo o procedimento fica a 'realidade' de dois testes de DNA, ambos com resultados negando a paternidade de Alceu. Todos os outros 
28 STRATHERN, 1992, 1995a e 1995b; Sarah FRANKLIN, 1995; Helena RAGONÉ, 1996; e Rayna RAPP, 2000. argumentos parecem pro forma, decretando o retorno de um silêncio desconfortável. É como se o teste dissesse tudo... "O menino tem direito de saber quem é o verdadeiro pai" soa como verdade moral. Contudo, nesse caso, a tecnologia do DNA está sendo usada não para elucidar quem é o pai, mas - antes - para dizer quem não é. E fica no ar a pergunta se alguém sai realmente ganhando.

\section{Olhares cruzados sobre parentesco e paternidade na época contemporânea}

Houve, no fim do século XX, um avanço nas ciências biomédicas que iria transformar a maneira como nós ocidentais concebemos o mundo. Na década de 1960 a pílula anticoncepcional foi popularizada, contribuindo para a consolidação de uma noção de sexualidade independente da concepção/reprodução. Foi também nessa época que as novas tecnologias reprodutivas deram um pulo, chegando, nas décadas seguintes, a abalar as concepções convencionais de reprodução. Com o primeiro bebê de proveta, ficou evidente que relações sexuais não eram a condição sine qua non da concepção. Com a 'barriga de aluguel', tornou-se possível duas mulheres (uma com o óvulo da outra implantado no seu útero) serem parceiras na procriação de um filho. Hoje, com a maternidade assistida, uma mulher pode ser mãe de sua própria irmã. E com as cirurgias transexuais as autoridades estatais estão procurando maneiras para classificar aquele pai que passou a ter um sexo feminino legal. Em outras palavras, os princípios 'básicos' da procriação - o casal exclusivamente heterossexual, a seqüência inevitável das gerações e a complementaridade sexual dos genitores não se mantêm mais, pelo menos não na sua forma original. Na visão de mundo da maioria dos ocidentais, a biologia não deixou de existir, mas - constantemente mexida pela intervenção humana - deixou de ser um dado bruto, que existe fora ou anterior à cultura. A cultura não é mais vista como uma força que opera a partir de (e sobre) uma natureza dada ou fixa. Entretanto, paradoxalmente, apesar da percepção de uma procriação assumidamente 'manmade', permanece mais forte do que nunca a idéia de que o parentesco é algo concreto, empiricamente demonstrável - através, por exemplo, do DNA. ${ }^{28}$

Não por acaso, houve, nessa mesma época, uma revolução na maneira em que antropólogos trabalhavam com a noção de família. Até então, os analistas tinham calcado suas análises em uma concepção genealógica de parentesco. A procriação sexuada era vista como o cerne de um sistema em que o sangue simbolizava a 
${ }^{29}$ David SCHNEIDER, 1984.

30 Vide o artigo clássico de LÉVISTRAUSS, 1966.

${ }^{31}$ Ver Janet CARSTEN, 2000.

32 Peter GOW apud Marilyn STRATHERN 1999, p. 77. proximidade ou distância entre um indivíduo e seus parentes. Da mesma forma que a família conjugal composta de um casal heterossexual e seus filhos biológicos - era 'inscrita na natureza', o parentesco, concebido como irradiando em círculos concêntricos, de um 'núcleo' familiar até os primos mais afastados, era visto como algo universal, comum a todas as sociedades humanas. A revolução ocorreu em um clima de reviravolta epistemológica, quando os antropólogos voltaram seu olhar para sua própria sociedade e, por extensão, para sua própria ciência. Surgiu então a dúvida, que em pouco tempo tornou-se convicção generalizada, de que as noções de 'família' e 'parentesco' que, até então, guiavam o olhar dos pesquisadores nada mais eram do que crenças folk da sociedade do pesquisador. Em outras palavras, ao tomar as crenças e os valores de sua cultura particular (América do Norte e Europa Ocidental) como parâmetro de observação válido para toda a humanidade, os antropólogos da primeira metade do século $X X$, quase por unanimidade, tinham cometido o pecado capital da disciplina - etnocentrismo. ${ }^{29}$

Não bastava mais relativizar 'a família', reconhecendo a enorme variabilidade de formas que esta assumia. ${ }^{30}$ Agora, desgarrando-se dos mapas genealógicos e procurando entender como seus informantes definiam os indivíduos mais relevantes de seu universo social, os antropólogos tiveram de reconhecer que muitos povos não calculam a proximidade ou distância social conforme os princípios da procriação sexuada tão valorizada na nossa sociedade. Da mesma forma que ocidentais consideram o sêmen e o sangue do ato sexual como vetores de substância compartilhada entre pais e filhos, há povos que concebem o ato de amamentar, de compartilhar comida ou mesmo de produzir alimentos juntos como símbolos de conexão tão (senão mais) poderosos do que o ato sexual. ${ }^{31}$ Assim, pesquisadores citam exemplos como o dos Piró da Amazônia, em que o vínculo de parentesco é constituído no ato de alimentar a criança. Do ponto de vista dos Piró, é a memória do processo alimentício que informa a definição de vínculos. Nesse contexto, a informação sobre origens fisiológicas traz um conhecimento de interesse secundário. Não é essa a informação que vai informar a percepção do indivíduo sobre seu lugar no mundo, sobre as relações que serão mais significativas para sua identidade. ${ }^{32}$ Tais dados apóiam o novo consenso de que a proximidade genealógica é apenas um e nem sempre o mais importante dos critérios usados para calcular pertencimento ao grupo 'primário'.

Essa discussão se torna particularmente relevante quando direcionada, como em boa parte da literatura atual 
${ }^{33}$ FRANKLIN, 1995.

${ }^{34}$ STRATHERN, 1999.

${ }^{35}$ STRATHERN, 1999, p. 75.

${ }^{36}$ STRATHERN, 1999, p. 82.

37 Judith STACEY, 1992; e BILAC, 1999. sobre parentesco, para o questionamento das categorias ocidentais de conhecimento. ${ }^{33}$ Strathern, ${ }^{34}$ em um recente estudo sobre o conhecimento de parentesco (kinship knowledge), argúi que, no contexto euro-americano, esse tipo de conhecimento está intimamente ligado à identidade pessoal. Para desenvolver seu raciocínio, faz uma distinção entre, por um lado, "informação reguladora", que se acrescenta ao conhecimento já existente, aumentando ou, pelo menos, esclarecendo opções práticas, e, por outro, "informação constitutiva", que implica uma redefinição total do jogo. Para ilustrar o primeiro tipo, mostra como, em certos casos, a informação fornecida pelo teste de DNA serve para converter um tipo de conhecimento em outro (a suspeita de paternidade alegada pela mãe vira fato), validando uma versão da realidade que já existia e ampliando as opções, por exemplo, da criança assim legitimada. Cita outros casos, no entanto, em que um homem faz uso do teste para negar a paternidade de crianças que vem criando há anos. Aqui, Stratherm sugere que a revelação de certa informação provoca uma reconfiguração total das relações: "a escolha entre um fato e outro é também uma escolha entre uma relação e outra. [...] uma informação pode automaticamente obliterar outra. Não se trata de escolhas. Os efeitos são embutidos na informação". 35

No sistema euro-americano, dada a centralidade do momento do coito, qualquer informação sobre a concepção provoca uma perturbação imediata nas relações e na identidade de um indivíduo. Este pode ter a opção de recusar certa informação (tem o direito de não saber), mas, uma vez revelada, ele não controla mais os efeitos da informação: "a informação constitutiva não pode ser selecionada conforme sua relevância ou aplicabilidade. Ou se sabe ou não se sabe". ${ }^{36}$ O fato de ter efeitos praticamente inevitáveis torna a tecnologia e, ainda mais, os especialistas da revelação mais poderosos do que nunca. Assim, investindo contra as máximas liberais quanto à virtude auto-evidente da livre circulação de informação e questionando o imperativo moral exigindo a revelação (disclosure) de praticamente tudo, Strathern faz um pleito provocador em favor da (possibilidade de) 'recusa de informação'.

O leitor poderia objetar que, no caso brasileiro, essas inquietações são pouco conseqüentes diante das benesses potenciais esperadas da identificação paterna por via do teste de DNA. Entretanto, como lembram diversos pesquisadores, ${ }^{37}$ o papel do pai-provedor é um ideal que muitos homens da classe trabalhadora nunca conseguiram atingir. Por causa de condições instáveis de trabalho, muitos deles não poderiam dar um apoio financeiro a seus filhos, 
38 Comparando as políticas sociais de diferentes países europeus, investigadores sugerem que as políticas francesas que investem na autonomia de mães de família (creches em tempo integral, subsídios familiares, ajudas especiais para mães ou pais solteiros, etc.) têm sido mais bemsucedidas do que aquelas (no caso da Inglaterra) que investem na identificação do genitor como se este fosse necessariamente promover o bem-estar de sua família (Nadine LEFAUCHEUR, 1996; e Claude MARTIN, 1996). mesmo que quisessem. No Brasil, ao que tudo indica, não são poucos os homens que negam sua paternidade justamente porque não possuem as mínimas condições para cumprir suas responsabilidades paternas. Nesse caso, é difícil conceber a investigação de paternidade como medida para o combate à pobreza. ${ }^{38}$ Sem nem essa vantagem garantida, o uso crescente do exame de DNA, com o conseqüente realce de 'verdades biológicas' na determinação legal de relações familiares, pode estar abrindo uma caixa de Pandora - com resultados ainda por serem vistos.

Certamente, o ciúme e a desconfiança não são elementos novos na relação entre parceiros de uma relação amorosa. Os clássicos, de Shakespeare a Machado de Assis, nos ensinam que dúvidas masculinas quanto à paternidade de uma criança existem há muito tempo. No entanto, sugiro que houve uma sutil modificação introduzida nessas relações pela grande importância atribuída à nova tecnologia, o teste de DNA de paternidade. Hoje, com a crescente importância legal do teste de DNA, e a possibilidade de saber 'a verdade real', homens e mulheres não têm mais a tranqüilidade para negociar sua própria verdade. Esta - a realidade supostamente objetiva - é dada fora deles por processos bioquímicos, nos laboratórios médicos. Não são mais os fatos da vida social (relações, afetos) que definem o 'verdadeiro' pai, mais sim os fatos biológicos que 'revelam' os comportamentos. Com isso, os homens têm medo de uma situação 'fora de lugar' e, em especial, que venha à tona, na opinião pública, que foram 'enganados', que tenham comido 'gato por lebre', que tenham aceitado, sem saber, a paternidade apenas social.

Desde a década de 1960, existem outros testes bastante seguros para verificar vínculos familiares. No entanto, o teste de DNA - com sua muito badalada precisão de $99,9999 \%$ - traz uma suposta certeza. Enquanto observava a coleta de sangue, ouvia uma pessoa atrás da outra perguntar: "É garantido?" "É definitivo?" "Pode dar erro?". E a resposta, dada pelos técnicos: "É infalível". Ainda mais significativo, os juízes chamados a arbitrar a investigação ou negação de paternidade não perdem mais tempo com testemunhas, indo em geral direto à prova 'contundente' do DNA. Nossas pesquisas preliminares sugerem que essa 'certeza' tecnológica está trazendo para - campo de relações familiares contemporâneas mudanças imprevistas. Longe de inspirar maior tranqüilidade, parece que a simples existência do teste atiça a vontade de saber. Nesse sentido, estamos diante da 'certeza que pariu a dúvida'. Ainda mais, trata-se de uma certeza técnica/biológica que pretende resolver 
dúvidas em torno de uma relação que é eminentemente social - a paternidade. Em outras palavras, a tecnologia está mudando as premissas das relações familiares e assim aumentando a dúvida que pretende sanar.

\section{Referências bibliográficas}

ALMEIDA, Miguel Vale de. Senhores de si: uma interpretação antropológica da masculinidade. Lisboa: Fim de Século, 1995.

ARILHA, Margareth. "Homens: entre a 'zoeira' e a 'responsabilidade'". In: ARILHA, Margareth; RIDENTI, Sandra G. Unbehaum; MEDRADO, Benedito (Orgs.). Homens e masculinidades: outras palavras. São Paulo: ECOS/Editora 34, 1998. p. 51-77.

BILAC, Elisabete D. "Mãe certa, pai incerto: da construção social à normatização jurídica da paternidade e da filiação". In: SILVA, Reinaldo Pereira; AZEVEDO, Jackson Chaves (Orgs.). Direitos da família: uma abordagem interdisciplinar. São Paulo: LTr Editora, 1999. p. 13-28.

CAMBOIM, Paula. "Gravidez na adolescência em grupos populares urbanos: conceções de idade e maternidade". In: ALMEIDA, Heloisa Buarque de et al. (Orgs.). Gênero em matizes. Bragança Paulista: Estudos CDAPH, 2002. p. 177-212.

CARSTEN, Janet. Cultures of Relatedness: New Approaches to the Study of Kinship. Cambridge: Cambridge University Press, 2000.

CONNELL, Robert W. Gender and Power: Society, the Person and Sexual Politics. Cambridge: Polity Press, 1987.

COSTA, Rosely G. "Mediando oposições: sobre as críticas aos estudos de masculinidades". In: ALMEIDA, Heloisa Buarque de et al. (Orgs.). Gênero em matizes. Bragança Paulista: Estudos CDAPH, 2002. p. 213-241.

FONSECA, Claudia. Caminhos da adoção. São Paulo: Editora Cortez, 1995. . Família, fofoca e honra. Porto Alegre: Editora da UFRGS, 2000.

. "A vingança de Capitu: DNA, escolha e destino na família brasileira contemporânea". In: BRUSCHINI, Cristina; UNBEHAUM, Sandra (Orgs.). Gênero, democracia e sociedade brasileira. São Paulo: Editora 34, 2002. p. 267-294.

FRANKLIN, Sarah. "Science as Culture, Cultures of Science." Annual Review of Anthropology, n. 24, 1995, p. 163-184.

GIFFIN, Karen; CAVALCANTI, Cristine. "Homem e reprodução". Revista Estudos Feministas, v. 7, n. 1-2, p. 53-71, 1999.

GUTMANN, Matthew C. The Meanings of Macho: Being a Man in Mexico City. Berkeley: University of California Press, 1996.

. "Traficando com hombres: la antropologia de la masculinidad". Horizontes Antropológicos, n. 10, p. 245-286, 1999.

. "Introduction: Discarding Manly Dichotomies in Latin America". In: GUTMANN, Matthew C. (ed.). Changing Men and Masculinities in Latina America. Durham: Duke University Press, 2003. p. 1-26.

LEAL, Ondina F; BOFF, Adriana. "Insultos, queixas, sedução e sexualidade: fragmentos de identidade masculina em uma perspectiva relacional". In: PARKER, Richard; BARBOSA, Regina. (Orgs.). Sexualidades brasileiras. Rio de Janeiro: Relume-Dumará, 1996. p. $119-135$. 
LEFAUCHEUR, Nadine. "Qui doit nourrir l'enfant de parents non-mariés ou démariés?: paradigmes de 'plus grand mal' et solutions de "moindre mal". In: DANDURAND, Renée; HURTUBISE, Roch; LE BOURDAIS, Celine (Orgs.). Enfances: perspectives sociales et pluriculturelles. Sainte-Foy: Presses de l'Université Laval, 1996. p. 99-112.

LEGALL, Didier; Claude MARTIN. "Construire un nouveau lien familial: beaux-parents et beauxgrands-parents”. In: GULLESTAD, Marianne; SEGALEN, Martine (Orgs.). La famille en Europe: parenté et perpétuation familiale. Paris: Editions La Découverte, 1995. p. 201-220.

LÉVI-STRAUSS, Claude. "A família". In: SHAPIRO, Harry (Org.). Homem, cultura e sociedade. Lisboa: Ed. Fundo de Cultura, 1966. p. 308-333.

LONGHI, Marcia. Ser homem, pobre e pai. 2001. Dissertação (Mestrado em Antropologia) - Universidade Federal de Pernambuco, Recife.

LYRA DA FONSECA, Jorge. "Paternidade adolescente: da investigação à intervenção". In: ARILHA, Margareth; RIDENTI, Sandra G. Unbehaum; MEDRADO, Benedito (Orgs.). Homens e masculinidades: outras palavras. São Paulo: ECOS/Editora 34, 1998. p. 185-214.

MARCONDES, Gláucia. "O vínculo paterno na separação e no recasamento". Paper apresentado no II Seminário Internacional/I Seminário Norte-Nordeste HOMENS, SEXUALIDADE E REPRODUÇÃO: Tempos, práticas, e vozes", (PAPAI/UFPE/UNICAMP), Recife, 17-20 de junho, 2003.

MARTIN, Claude. "L'enfant après la désunion: logique d'action publique en France et aux Royaumes-Unis". In: DANDURAND, Renée; HURTUBISE, Roch; LE BOURDAIS, Celine (Orgs.). Enfances: perspectives sociales et pluriculturelles. Sainte-Foy: Presses de l'Université Laval, 1996. p. 59-89.

MARTINEZ, Maria Josefina. "Paternidades contenciosas: un estudio sobre filiaciones, leyes e burocracias". In: TISCORNIA, Sofia (Org.). Burocracias y violencia: estudios de antropología jurídica. Buenos Aires: Antropofagia, 2004. p. 403-433.

NOLASCO, Sócrates. A descontrução do masculino. Rio de Janeiro: Rocco, 1995.

OLIVEIRA, Maria Coleta. "A família brasileira no limiar do ano 2000". Revista Estudos Feministas, v. 4, n. 1, p. 55-64, 1996.

PAIM, Heloisa. "Marcas no corpo: gravidez e maternidade em grupos populares". In: DUARTE, Luis Fernando; LEAL, Ondina F. (Orgs.). Doença, sofrimento, perturbação: perspectivas etnográficas. Rio de Janeiro: Fiocruz, 1998. p. 31-48.

RAGONÉ, Helena. "Chasing the Blood Tie: Surrogate Mothers, Adoptive Mothers and Fathers." American Ethnologist, v. 23, n. 2, 1996, p. 352-365.

RAPP, Rayna. Testing Women, Testing the Fetus: the Social Impact of Amniocentesis in America. New York: Routledge, 2000.

RIDENTI, Sandra. "A desigualdade de gênero nas relações parentais: o exemplo da custódia dos filhos". In: ARILHA, Margareth; RIDENTI, Sandra G. Unbehaum; MEDRADO, Benedito (Orgs.). Homens e masculinidades: outras palavras. São Paulo: ECOS/Editora 34, 1998. p. 163-184.

SCHNEIDER, David M. A Critique of the Study of Kinship. Ann Arbor: University of Michigan Press, 1984.

SCOT, Russel Parry. "O homem na matrifocalidade: gênero, percepção e experiências do domínio doméstico". Cadernos de Pesquisa, São Paulo, n. 73, p. 38-47, 1990.

SCOTT, Russel Parry; HOFFNAGEL, Judith C. (Orgs.). Revista AntHropológicas, UFPe, v. 4, n. 9 , 2001. Número Especial (Famílias, sexualidades, saúdes).

SIQUEIRA, Maria Juracy Toneli. A constituição do sujeito e a divisão sexual do trabalho na família: análise do caso de um homem dono-de-casa. 1997. Tese (Doutorado em Psicologia) - Programa de Pós-Graduação de Psicologia da USP, São Paulo. 
STACEY, Judith. "Backward Toward the Postmodern Family: Reflections on Gender, Kinship, and Class in the Silicon Valley." In: THORNE, Barrie, and YALOM, Marilyn (eds.). Rethinking the Family: Some Feminist Questions. Boston: Northeastern University Press, 1992. p. $91-$ 118.

STRATHERN, Marilyn. Reproducing the Future: Anthropology, Kinship, and the New Reproductive Technologies. New

. "Displacing Knowledge: Techology and the Consequences for Kinship." In: RAPP, Rayna, and GINSBURG, Faye (eds.). Conceiving the New World Order: the Global Politics of Reproduction. Berkeley: University of California Press, 1995a. p. 346-363.

. "Necessidade de pais, necessidade de mães". Revista Estudos Feministas, v. 3, n. 2, p. 303-329, 1995b.

"Refusing Information." In:

Property, Substance and Effect: Anthropological Essays on Persons and Things. London: Athlone Press, 1999. p. 64-86.

VICTORA, Ceres. "As relações de gênero na Vila Divina Providência ou o que elas esperam deles". Cadernos de Antropologia, n. 7 (Cultura e identidade masculina), p. 15-28, 1992.

VIGOYA, Mara Viveros. "Contemporary Latin American Perspectives on Masculinity." In: GUTMANN, Matthew C. (ed.). Changing Men and Masculinities in Latina America. Durham: Duke University Press. 2003. p. 27-57.

[Recebido em dezembro de 2003 e aceito para publicação em janeiro de 2004]

\section{The Certainty that Engendered New Doubts: DNA and Paternity Tests}

Abstract: DNA paternity tests, in both private and public laboratories, have become popular of late throughout Brazil, raising some interesting questions as to the overlap of the legal and medical spheres in family issues. To analyze this question, we accompanied people involved in paternity disputes presenting their claims in the different judicial instances of Porto Alegre, RS (Defensoria, conciliation sessions, the court medical service, and the Family Court). We also examined how the different actors involved in this scenario interacted with recent Brazilian legislation dealing with paternity. On the basis of this experience, we raise the hypothesis that, far from inspiring greater tranquility, the simple existence of this test stirs up doubts. Reflecting profound repercussions for our manner of "knowing" paternal identity, reactions to the DNA test described in this paper also raise questions relevant to an anthropology of knowledge, centered on Western beliefs on science and kinship.

Key words: paternity, reproduction, family law, DNA technology, gender relations. 